\title{
Chronic abdominal pain caused by a large haemangiosarcoma in the retroperitoneal space
}

\author{
Olbrzymia zmiana typu haemangiosarcoma przestrzeni zaotrzewnowej jako \\ przyczyna dolegliwości bólowych brzucha
}

\author{
Andrzej Prystupa ${ }^{1}$, Ewa Kurys-Denis ${ }^{2}$, Roman Styliński ${ }^{3}$, Tomasz Pedowski ${ }^{3}$, Grzegorz Ćwik ${ }^{3}$, Jolanta Mieczkowska ${ }^{1}$ \\ Barbara Jodłowska-Jędrych ${ }^{4}$, Andrzej Dąbrowski ${ }^{3}$, Grzegorz Wallner ${ }^{3}$, Jerzy Mosiewicz' ${ }^{1}$ Witold Krupski \\ ${ }^{1}$ Department of Internal Medicine, Medical University, Lublin, Poland \\ $2^{2}{ }^{\text {nd }}$ Department of Radiology, Medical University, Lublin, Poland \\ ${ }^{3} 2^{\text {nd }}$ Department of Surgery, Medical University, Lublin, Poland \\ ${ }^{4}$ Department of Histology and Embryology, Medical University, Lublin, Poland
}

Przegląd Gastroenterologiczny 2011; 6 (3): 195-200

DOI: 10.5114/pg.2011.22804

Key words: chronic abdominal pain, haemangiosarcoma.

Słowa kluczowe: przewlekłe bóle brzucha, haemangiosarcoma.

Address for correspondence: Andrzej Prystupa MD, Department of Internal Medicine, Medical University, 16 Staszica, 20-081 Lublin, Poland, tel./fax +48 8153277 17, e-mail: aprystup@mp.pl

\begin{abstract}
A 55-year-old patient was admitted to the Department of Internal Medicine due to pain in the intra-abdominal and lumbar region. Abdominal ultrasound and CT scans demonstrated a large tumour in the retroperitoneal space infiltrating the spleen, left kidney and gastric wall. The patient underwent resection of the tumour infiltrating the spleen, left kidney and a part of the stomach; histopathological examination showed the presence of haemangiosarcoma.
\end{abstract}

\section{Introduction}

Management of patients with chronic abdominal pain is a common cause of referral to gastroenterologists. The definition of chronic abdominal pain used clinically and in research over the last 40 years has used the criterion of at least 3 pain episodes over at least 3 months interfering with function [1]. In clinical practice, it is generally believed that pain that exceeds 1 or 2 months in duration can be considered chronic. There are many possible causes of pain. Epidemiological studies suggest that the vast majority of patients with chronic abdominal pain have functional gastrointestinal (GI) disorders such as irritable bowel syndrome or functional dyspepsia. However, the pain associated with these disorders is non-specific and can resemble or co-exist with organic disorders. Chronic abdominal pain may be

\section{Streszczenie}

Chora 55-letnia została przyjęta na oddział chorób wewnętrznych z powodu dolegliwości bólowych brzucha w okolicy śródbrzusza i lędźwiowej. Na postawie wykonanych badań obrazowych - ultrasonografii jamy brzusznej i tomografii komputerowej - u chorej stwierdzono dużego guza w przestrzeni zaotrzewnowej. Wykonano resekcję chirurgiczną guza naciekającego śledzionę, lewą nerkę i część żołądka, a następnie przeprowadzono badanie histopatologiczne, które wykazało obecność haemangiosarcoma.

caused by many benign as well as malignant organic diseases: pancreatitis, cholecystitis, peptic ulcer disease, inflammatory bowel disease, intestinal ischaemia, abdominal aortic aneurysm and cancers.

We report a rare presentation of a large angiosarcoma in the retroperitoneal cavity characterized by chronic abdominal pain and weight loss.

\section{Case report}

A 55-year-old female patient was admitted to the department due to pain in the intra-abdominal and lumbar region, which had intensified over the last 3 months. The patient lost $5 \mathrm{~kg}$ over the 2 months prior to hospitalization. At the age of 35, the patient had a car accident and sustained a severe injury to the subcostal region caused by a steering wheel. The pain sensations 
resolved spontaneously. At the age of 42 , the patient experienced an attack of severe pain in the left lumbar region. Abdominal ultrasound examination showed the presence of a 2-chamber cyst in the upper pole of the left kidney. An attack of pain in the left lumbar region recurred at the age of 46 . Repeated abdominal ultrasound imaging revealed a multi-chamber cyst in the upper pole of the left kidney.

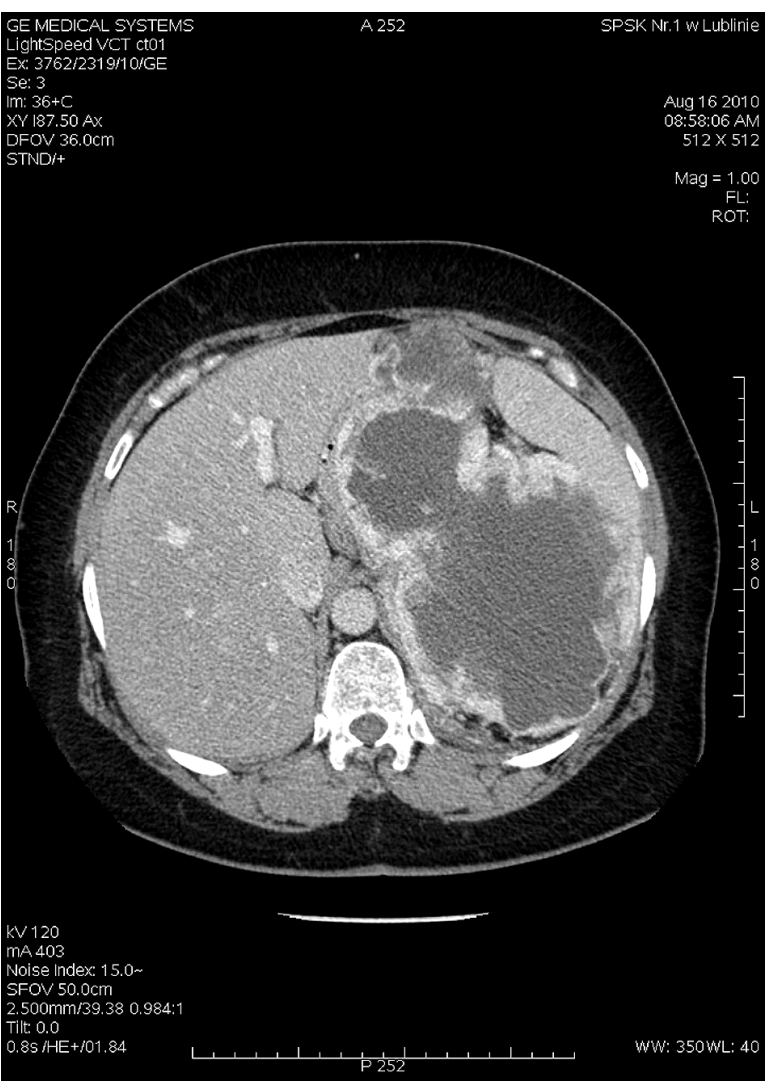

Fig. 1. Computed tomography of the abdomen during intravenous contrast medium administration demonstrates a voluminous, predominately necrotic mass in the left retroperitoneum, with a relatively thin and irregular rim of peripheral enhancement. The mass is closely touching and invading the lower part of the spleen. Duodenum is compressed and abdominal aorta slightly moved to the right

Ryc. 1. Obraz TK jamy brzusznej po podaniu środka kontrastowego ukazuje zlokalizowana pozaotrzewnowo, po stronie lewej, olbrzymia mase tkankowa z dużymi obszarami nekrozy oraz ze względnie cienka i nieregularna strefą obwodowego wzmocnienia. Patologiczna masa przylega ściśle i częściowo nacieka dolny biegun śledziony. Dwunastnica jest uciśnięta, a aorta brzuszna przesunięta częściowo na prawą stronę ciała
The patient has been treated for arterial hypertension for 4 years, systematically taking the prescribed drugs. At the age of 47, the patient underwent nodular goitre surgery. The histopathological findings demonstrated microfollicular adenoma. Due to postoperative hypothyroidism, the patient received oral thyroxine. Moreover, in childhood the patient underwent appendectomy. Her medical history revealed deep venous thrombosis of the lower limbs. The patient had 3 spontaneous labours. The family history disclosed myocardial infarction in her father and arterial hypertension in her mother.

On admission, arterial hypertension was $120 / 80 \mathrm{mmHg}$ and BMI was $33.83 \mathrm{~kg} / \mathrm{m}^{2}$. Physical examination showed tenderness on deep palpation in the left and right subcostal region. Moreover, on deep palpation, a tumour $20 \times 25 \mathrm{~cm}$ located in the left subcostal region was detected. Goldflam's sign was bilaterally negative. Per rectal examination did not show any lesions or haemorrhage. The heart rate was regular and accelerated to $100 /$ min. Vesicular murmur was heard over the lung fields.

Laboratory tests demonstrated anaemia with a haemoglobin level of $10.6 \mathrm{~g} \%$ (norm 12-16 g\%), MCV $87 \mathrm{fl}$ and thrombocytopenia $102 \mathrm{~K} / \mu \mathrm{l}$ (norm 120-400 K/ $\mu \mathrm{l}$ ). Parameters of renal and hepatic function were normal. Likewise, levels of thyroid hormones FT3 and FT4 were normal. The CRP level was elevated, $35 \mathrm{mg} / \mathrm{l}$ (norm $<5 \mathrm{mg} / \mathrm{l})$. The level of D-dimer was also high, $5203 \mathrm{ng} / \mathrm{ml}$ (norm $<500 \mathrm{ng} / \mathrm{ml}$ ). The 24-hour secretion profiles of cortisol and ACTH were normal. Additionally, the test of cortisol secretion inhibition with $1 \mathrm{mg}$ of dexamethasone was also found normal. The concentration of catecholamines from the 24-hour urine collection was within the reference values whereas the levels of cholesterol (211 mg/dl) and triglycerides (219 mg/dl) were elevated.

During the present hospitalization, the patient underwent abdominal ultrasound examination which showed the presence of a polycyclic fluid-tissue area in the upper pole of the left kidney; maximum diameter was $12.4 \times 11.1 \mathrm{~cm}$, frontally $11.6 \mathrm{~cm}$. The largest fluid space (multi-chamber) was $8.8 \times 7.4 \mathrm{~cm}$ and reached the splenic hilus and pancreatic tail. Both kidneys were without urinary retention or large deposits. The spleen was enlarged, with a maximum diameter of $140 \times 34 \mathrm{~mm}$. The thoracic X-ray picture was normal whereas the lumbar spine image showed degenerative changes. Electrocardiography revealed sinus rhythm. The patient underwent abdominal Computed tomography (CT) and was scheduled for tumour resection. Computed tomography of the abdomen showed a multilobular, expansile process of the retroperitoneum, in the left adrenal fossa, which stretched between the left kidney, stomach and the spleen and showed an infiltrating pattern of growth 


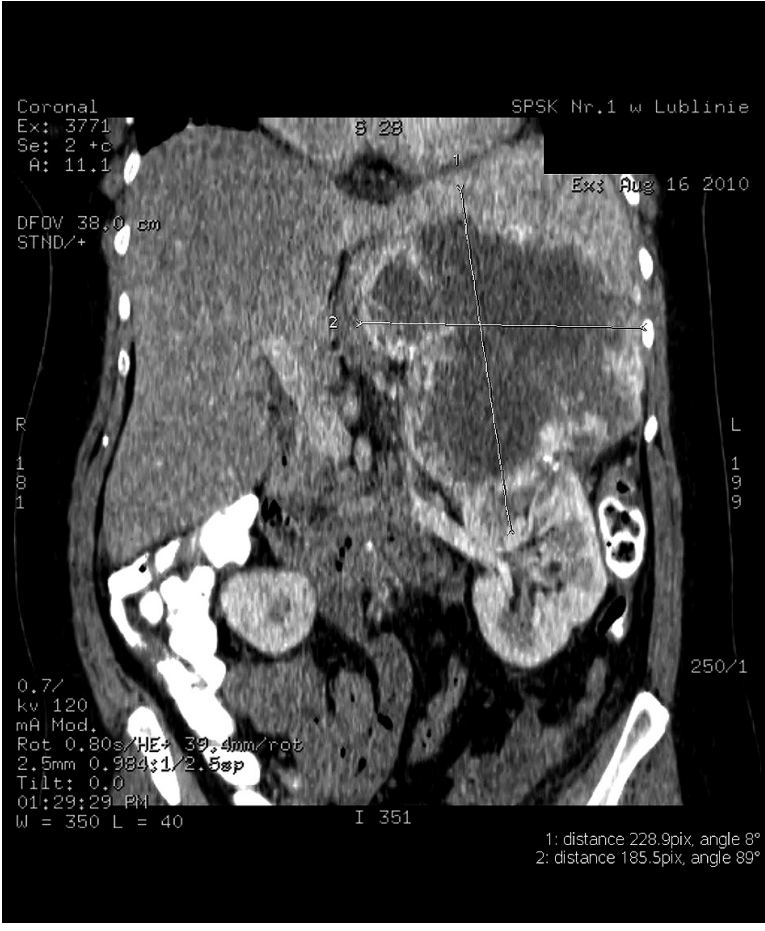

Fig. 2. Coronal reformatted post-contrast CT image shows a huge mass measuring $23 \times 18.5 \mathrm{~cm}$ with strong and irregular enhancement of the soft tissue components. The lower part invades the upper pole of the left kidney

Ryc. 2. Rekonstrukcja w płaszczyźnie wieńcowej TK po podaniu środka kontrastowego przedstawia olbrzymia masę patologiczna o wymiarach 23 × 18,5 cm. Część miękkotkankowa masy ulega silnemu i niejednorodnemu wzmocnieniu kontrastowemu. Część dolna guza nacieka górny biegun nerki lewej

and extensive necrotic changes centrally (Figures 1-3). The mass measured about $23 \times 18.5 \times 15.5 \mathrm{~cm}$ and displayed a strong but irregular enhancement of the soft tissue components after intravenous contrast administration. In the location of the former left adrenal gland, multiple large and rather regular calcifications were observed. The mass invaded the upper pole of the left kidney and the lower part of the spleen.

Laparotomy was performed and an extensive retroperitoneal solid tumour was found. The tumour extended from the oesophageal-gastric junction down through the greater curvature, which was infiltrated as well as the spleen and the left kidney. The resected tumour length with resection margins was about $25 \mathrm{~cm}$ and width about $20 \mathrm{~cm}$. The tumour was resected in two specimens along with the greater curvature of the stomach, spleen and left kidney (Figure 4).

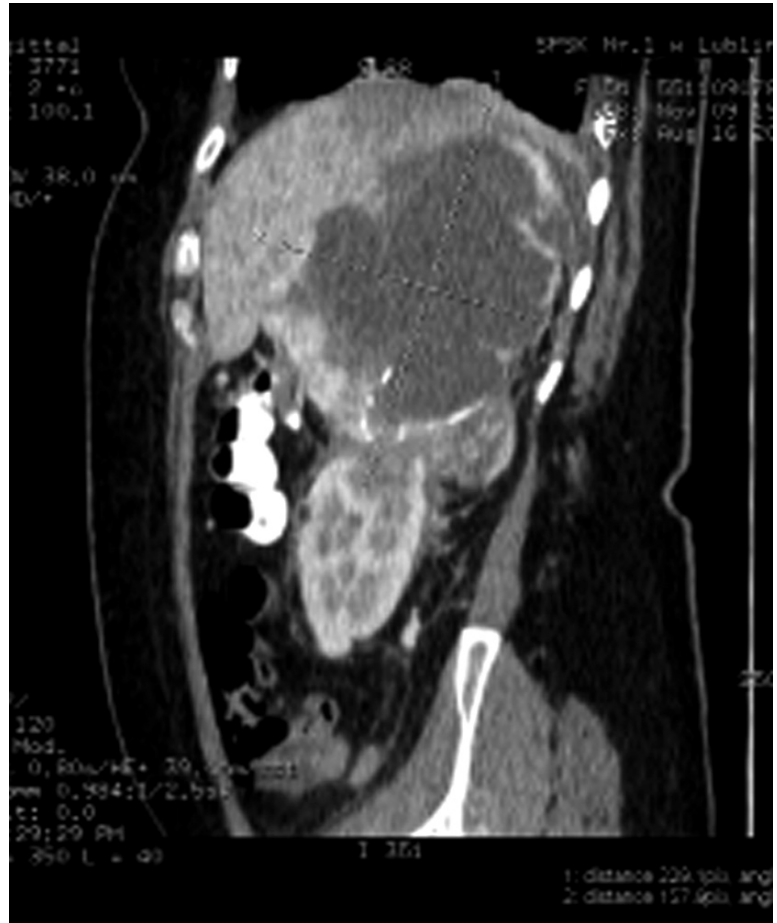

Fig. 3. Sagittal reformatted post-contrast CT image shows an expansion of the huge mass measuring $23 \times 15.5 \mathrm{~cm}$ which invades the spleen and the upper pole of the left kidney. The lower part of the mass contains large and vaguely regular calcifications. The predominately hypodense component shows no increase in density and therefore corresponds with extensive necrosis

Ryc. 3. Rekonstrukcja w płaszczyźnie strzatkowej TK po podaniu środka kontrastowego obrazuje ekspansję dużego guza o wymiarach $23 \times 15,5 \mathrm{~cm}$, który nacieka śledzionę oraz górny biegun nerki lewej. W części dolnej masy widoczne sa duże i regularne zwapnienia. Większa, hipodensyjna część guza nie wykazuje wzmocnienia kontrastowego, co odpowiada obszarom rozległej nekrozy

Three free drains were left. Based on the histopathological findings of the resected tumour, haemangiosarcoma G2/G3 was diagnosed (Figure 5).

During postoperative hospitalization, the patient's condition gradually improved; she underwent pleurocentesis due to the presence of fluid in both pleural cavities. Her condition further improved and she was discharged home in good condition; regular check-ups in the surgical and oncological outpatient clinic as well as future chemotherapy were scheduled. 

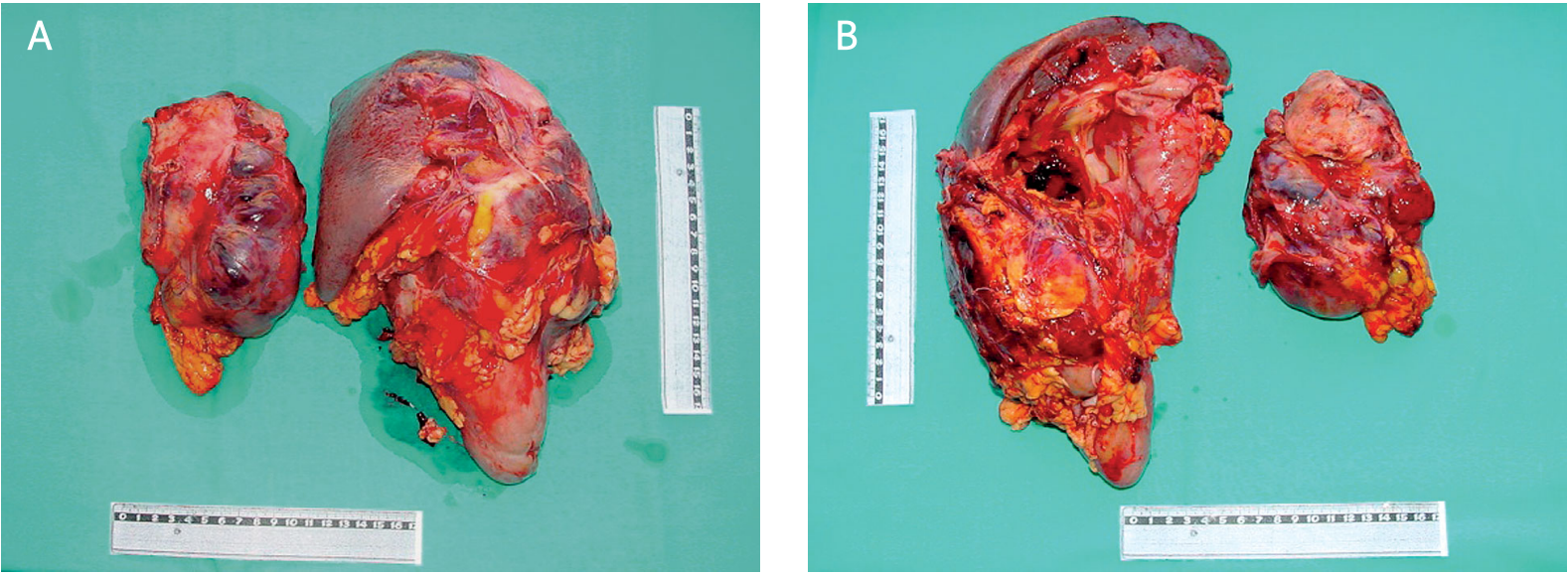

Fig. 4. Resected tumour of haemangiosarcoma infiltrating left kidney, spleen and part of stomach - anterior (A) and posterior (B) surface

Ryc. 4. Wycięty guz haemangiosarcoma naciekający lewą nerkę, śledzionę i część żołądka - powierzchnia przednia (A) i tylna (B)

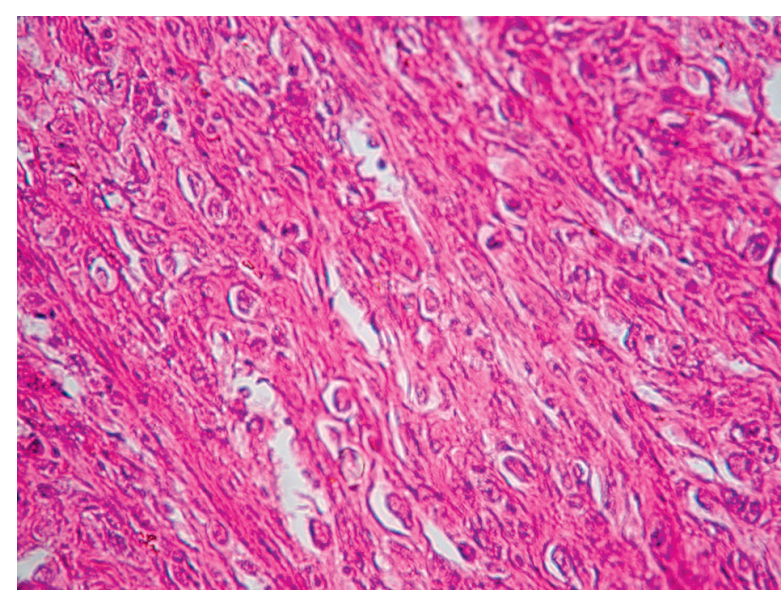

Fig. 5. Histological section demonstrating the haemangiosarcoma $(\mathrm{HE} \times 200)$

Ryc. 5. Obraz histologiczny odpowiadajacy haemangiosarcoma (HE $\times 200)$

\section{Discussion}

Angiosarcomas are a subtype of soft-tissue sarcoma and are aggressive, malignant endothelial cell tumours of vascular or lymphatic origin. Treatment is challenging in many cases and the prognosis is poor. Angiosarcomas are subdivided into cutaneous angiosarcoma, lymphoedema-associated angiosarcoma, radiation-induced angiosarcoma, primary breast angiosarcoma, and soft tissue angiosarcoma, and most reports include several angiosarcoma subtypes [2]. About $2 \%$ of soft tissue sarcomas and $5.4 \%$ of cutaneous soft tissue sarcomas are angiosarcomas [3].

Based on data from the Surveillance, Epidemiology, and End Results programme, $4.1 \%$ of angiosarcomas were diagnosed in 26,758 cases of soft tissue sarcoma available for analysis from 1978 to 2001 . The 5-year survival for soft tissue sarcomas is $67 \%$. The mortality for soft tissue sarcomas was around 1.6 cases per 100,000 population in 2000 [4].

Angiosarcoma can arise in any soft tissue structure or viscera and cutaneous angiosarcomas typically involve the head and neck, particularly the scalp. Angiosarcomas are of endothelial cell origin and tumours arising directly from major blood vessels or the heart are rare.

In the case described, the tumour was mainly located in the retroperitoneal space and infiltrated the left kidney, spleen and gastric wall. The patient did not report severe abdominal pain for a long period. The follow-up ultrasound scans showed cystic lesions in the left renal region.

Retroperitoneal angiosarcomas usually present as asymptomatic masses and generally grow to large sizes because the abdomen can accommodate tumours. Patients may present with neurological symptoms from compression of lumbar or pelvic nerves.

Retroperitoneal sarcomas are well known to present difficulties in their complete resection because of their inaccessible location and the absence of early symptoms, resulting in tumours of large size by the time the diagnosis is made. A collective review article that analysed the reports of retroperitoneal soft tissue sarcomas from major centres found that complete resection was possible in $53 \%$ of patients treated in major centres, with a 5-year survival rate of only $34 \%$ of patients [5].

About 13 years before the present hospitalization, the patient was diagnosed with a multi-chamber cyst in the upper pole of the left kidney. Since then, the patient has 
reported recurrent abdominal pain. The exact onset time of tumour development is not known. The tumour might have grown slowly, inducing increasingly severe pain. In the preoperative period, pain sensations increased due to the large size of the tumour and infiltration of the spleen, left kidney and gastric wall. Laboratory tests excluded hormonal activity of the tumour as for secretion of cortisol and catecholamine derivatives. The primary site of tumour proliferation might have been the retroperitoneal space, spleen or left kidney. The tumour was mostly located in the retroperitoneal space. Its presence was confirmed by abdominal CT. Haemangiosarcoma of the adrenals has no functional activity. Urinary catecholamines and corticosteroid metabolites were all within the normal limits in our patient.

Computed tomography is the most useful tool in the evaluation of retroperitoneal tumours. A CT scan allows not only assessment of the tumour's location and its relationship to adjacent organs, but also identification of metastatic lesions in the liver or peritoneal cavity. In addition, characterization of fatty tumours and detection of intra-abdominal metastasis are possible with CT scanning of the abdomen.

The appearance of adrenal haemangiosarcomas in the various imaging modalities is non-specific. Nonenhanced CT usually shows a heterogeneous suprarenal mass with necrotic changes, massive liquefaction, and peripheral contrast enhancement. Many neoplasms may be confused with the haemangiosarcoma [6].

Adrenal cortical carcinoma is the most important differential diagnosis to consider, but other neoplasms such as pheochromocytoma, metastatic malignancies, retroperitoneal mesenchymal tumours, and adrenal adenomas undergoing massive haemorrhage may simulate the appearance of an angiosarcoma [7]. Differentiation between these lesions cannot be obtained by imaging alone; resection or biopsy must be performed to reach the definitive diagnosis.

The common causative factors for angiosarcoma are: trauma, lymphoedema, radiation, foreign bodies, thorium dioxide, and viral infection [8]. In our case, at the age of 35, the patient had sustained an injury to the region where the tumour developed. This injury might have been the causative factor of angiosarcoma.

In vivo studies have shown that vascular damage and vascular flow predispose to metastasis and that increased numbers of tumour cells lodge at the site of trauma [9]. It has been postulated that basic fibroblast growth factor (b-FGF), released from traumatized tissue, plays an important role in the development of the Koebner phenomenon [10] and may lead to the development of a tumour [11]. Haematogenous seeding of tumour cells at the site of trauma and b-FGF synthesized in the tumour endothelial cells may play a key role in the growth and progression of angiosarcoma.

It seems that the tumour primarily proliferated in the retroperitoneal space, infiltrating the left kidney and later the spleen and gastric wall. During surgery, the tumour was resected together with the spleen, left kidney and a part of the stomach. It is likely that the tumour primarily originated from the spleen or gastric wall and further proliferated to the retroperitoneal space and infiltrated the left kidney.

Primary malignant vascular neoplasms of the spleen are rare and carry a dismal prognosis regardless of the treatment regimen. Neuhauser et al. described 28 cases of primary splenic angiosarcoma. The majority of patients (75\%) complained of abdominal pain, generalized weakness, fatigue, malaise, and fever, and $25 \%$ presented with splenic rupture. The most common physical finding was splenomegaly (71\%) [12].

Angiosarcoma involving the kidney usually represents metastasis from skin or visceral primary lesions, while angiosarcoma primarily occurring in the kidney is a very rare neoplasm. In the English literature since 1942, only 19 cases of primary kidney angiosarcoma have been reported. The most common clinical manifestations of renal angiosarcoma at the time of diagnosis are the presence of haematuria, palpable mass and flank pain [13].

Angiosarcoma of the Gl tract is rarely reported in the literature. Among reported cases, only two were of primary gastric angiosarcoma, but both were symptomatic, and none presented as a gastric submucosal tumour. Tai et al. reported a 55-year-old man with primary gastric angiosarcoma presenting as an asymptomatic gastric submucosal tumour [14].

Angiosarcoma is a rare neoplasm that may develop in the retroperitoneal space. Due to this localization of angiosarcoma, the diagnosis and treatment of the tumour is delayed. In our case, the patient had been formerly diagnosed with a multi-chamber cyst in the upper pole of the left kidney which caused recurrent abdominal pain for 13 years and might have interfered with the growing pain caused by tumour growth in the left retroperitoneal space. In such patients, it is therefore especially important to keep in mind their earlier medical history. Our patient had undergone a large postaccident operation in the region where the tumour developed, which might have been a possible causative factor for the haemangiosarcoma. Taking this into consideration, any sudden change or growing intensity of abdominal pain should be further diagnosed in such patients. When angiosarcoma is suspected on ultrasound examinations, abdominal CT and histopathological examinations should be conclusive. 


\section{References}

1. Apley J. The child with recurrent abdominal pain. Pediatr Clin North Am 1967; 14: 63-72.

2. Weiss SW, Goldblum JR. Enzinger \& Weiss's soft tissue tumors, $5^{\text {th }}$ ed. Mosby, 2008.

3. Coindre JM, Terrier P, Guillou L, et al. Predictive value of grade for metastasis development in the main histologic types of adult soft tissue sarcomas: a study of 1240 patients from the French Federation of Cancer Centers Sarcoma Group. Cancer 2001; 91: 1914-26.

4. Schottenfeld D, Fraumeni J (eds.). Cancer. Epidemiology and Prevention. $3^{\text {rd }}$ ed. Oxford University Press, New York 2006.

5. Stom FK, Mahvi DM. Diagnosis and management of retroperitoneal soft-tissue sarcoma. Ann Surg 1991; 21: 2-10.

6. van Haelst UJ, Pruszczynski M, ten Cate LN, Mravunac M. Ultrastructural and immunohistochemical study of epithelioid hemangioenthelioma of bone: coexpressiom of epithelial and endothelial markers. Ultrastruct Pathol 1990; 14: 141-9.

7. Ferrozzi F, Tognini G, Bova D, et al. Hemangiosarcoma of adrenal glands: CT findings in two cases. Abdom Imaging 2001; 26: 336-9.

8. Naka N, Ohsawa M, Tomita Y, et al. Angiosarcoma in Japan. A review of 99 cases. Cancer 1995; 75: 989-96.

9. Fisher B, Fisher ER, Feduska N. Trauma and the localization of tumor cells. Cancer 1967; 20: 23-30.

10. French PD, Harris JR, Mercey DE. The Koebner phenomenon and AIDS-related Kaposi's sarcoma. Br J Dermatol 1994; 131: 746-7.

11. Sharpe RJ, Arndt KA, Bauer SI, Maione TE. Cyclosporine inhibits basic fibroblast growth factor-driven proliferation of human endothelial cells and keratinocytes. Arch Dermatol 1989; 125: 1359-62.

12. Neuhauser TS, Derringer GA, Thompson LD. Splenic angiosarcoma: a clinicopathologic and immunophenotypic study of 28 cases. Mod Pathol 2000; 13: 978-87.

13. Johnson VV, Gaertner EM, Crothers BA. Fine-needle aspiration of renal angiosarcoma. Arch Pathol Lab Med 2002; 126: 478-80.

14. Tai CM, Hung CM, Lee TC, et al. Primary gastric angiosarcoma presenting as an asymptomatic gastric submucosal tumor. J Formos Med Assoc 2007; 106: 961-4. 